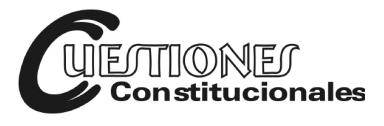

Revista Mexicana de Derecho Constitucional

Núm. 26, junio-diciembre 2012

\title{
LA PROBABLE INEJECUCIÓN DE LAS SENTENCIAS DE LA CORTE INTERAMERICANA DE DERECHOS HUMANOS
}

\author{
THE LIKELY NONPERFORMANCE OF JUDGMENTS \\ OF THE INTER-AMERICAN COURT OF HUMAN RIGHTS
}

Eréndira SALGADO LEDESMA*

\begin{abstract}
RESUMEN: En el ámbito internacional han evolucionado las obligaciones pactadas en los diversos instrumentos en materia de derechos humanos y los parámetros de interpretación y protección de los organismos que velan por su eficacia. Y si bien la suscripción de un tratado y el sometimiento a la jurisdicción de la Corte Interamericana son decisiones que un Estado adopta de forma potestativa en ejercicio de su soberanía; una vez signado aquél y aceptada ésta, el tribunal queda facultado para contrastar si se cumplen las obligaciones contraídas. En caso negativo dicta una sentencia reparadora, definitiva e inatacable. Ocasionalmente las reglas $\mathrm{y}$ criterios que rigen su actividad contenciosa son cuestionados; se argumenta incertidumbre en su competencia y extralimitación en sus atribuciones, pese a ello sus fallos se acatan. Sin embargo, Venezuela recién exploró un inusual recurso ante su Corte Suprema para inobservar una sentencia dictada en su contra.
\end{abstract}

ABSTRACT: In the international arena have evolved the obligations agreed to at the various instruments in the field of human rights and the performance parameters and protection of the bodies to ensure its effectiveness. And while the signing of a treaty and the submission to the jurisdiction of the Inter-American Court are decisions that a State adopts the equation form within the exercise of sovereignty; once marked that and accepted this, the court is entitled to compare if it meet the obligations. In case negative dictates a judgment restorative, final and unassailable. Occasionally the rules and criteria that govern its contentious activity are questioned; it argues uncertainty in their competence and overstepping its powers, despite his judgments are compliant.

Descriptors: international jurisdiction, subsidiary law, hierarchy of the treaties, control of conventionality, effective protection of rights.
Palabras clave: jurisdicción internacional, derecho subsidiario, jerarquía de los tratados, control de convencionalidad, tutela efectiva de derechos.

* Miembro del Sistema Nacional de Investigadores, Conacyt; Universidad Anáhuac México Norte. 


\section{CONSIDERACIONES PRELIMINARES}

Los instrumentos de control previstos en la Constitución Política de los Estados Unidos Mexicanos (Constitución) siguen siendo insuficientes para contener las arbitrariedades de las autoridades; bien por fallas en su diseño o por decisión de éstas. Contamos con múltiples remedios procesales - casi una docena de garantías constitucionales-, pero el recurso para la tutela de los derechos fundamentales se convirtió en una institución procesal añeja, mal sistematizada y sumamente compleja para cumplir los objetivos para los que fue creado. ${ }^{1}$ La configuración del juicio de amparo resultó insuficiente para lograr la protección eficaz de los derechos humanos y motivó la necesidad de complementarlo con todo un sistema no jurisdiccional para su defensa. A tal fin se instituyó un ombudsman nacional y uno en cada entidad federativa dotados cada vez de mayores atribuciones así como diversas instancias protectoras del gobernado en sede administrativa. ${ }^{2}$ El sistema de "defensores del pueblo" se complementó con el "amparo trasnacional"; instancia jurisdiccional a cargo de la Corte Interamericana de Derechos Humanos (Corte Interamericana) que posibilita verificar la actuación de las autoridades administrativas y ocasionalmente la conformidad de las determinaciones de los jueces a fin de contrastarlas con los mandatos de la Convención Americana sobre Derechos Humanos (Convención Americana) para determinar si el Estado mexicano cumple o no con los compromisos internacionales en la materia; suele suceder que no, seis condenas lo evidencian. En este entorno, los doctrinarios suelen perderse en discusiones hipotéticas y los procesalistas privilegiamos la observancia de las reglas y los procedimientos. Y ambos "perdemos de vista" los objetivos para los cuales fueron diseñados los instrumentos de control. De los litigantes ni hablamos: entre más compleja sea la defensa les redituará mayores dividendos. Por ello, en la mayoría de los países de América Latina siguen siendo persistentes tanto las arbitrariedades de los agentes estatales como la lucha de muchos por garantizar su vigencia efectiva. Surgen así dos preguntas obligadas: ¿cómo construimos mejores herramientas

Cfr. Ferrer Mac-Gregor, Eduardo, Del amparo nacional al amparo internacional, http://www.enj.org/portal/biblioteca/civil/amparo/11.pdf.

2 Cfr. Salgado Ledesma, Erendira, Defensa de usuarios y consumidores, México, Porrúa, 2007, pp. 16-29. 
para la defensa de los derechos fundamentales?, y ¿cómo protegemos los derechos humanos para que no se conviertan en declaraciones carentes de firmeza? Su defensa tampoco ha estado exenta de cuestionamientos; algunos involucran tanto la jurisdicción de la Corte Interamericana como la actuación de algunos estados frente a sus resoluciones: ¿está obligado el Estado condenado a acatar cualesquier sentencia de la Corte, más allá de los compromisos signados? ¿Deben cumplirse los fallos si la Corte excediere su competencia y atribuciones y en ellos planteara determinaciones; no de naturaleza subsidiaria, sino esencial que se estimaran atentatorias de la soberanía del Estado suscriptor del tratado? Sus criterios interpretativos, ¿deben aplicarse de forma preeminente sobre la jurisprudencia de los tribunales nacionales? Las preguntas son muchas. El análisis y la discusión apenas iniciaron.

\section{OBLIGACIONES INTERNACIONALES}

Los estados crean y actualizan el derecho en los planos interno e internacional en ejercicio de su soberanía. Cuando han suscrito y ratificado alguna obligación internacional deben actuar asumiendo las responsabilidades que conlleva. ${ }^{3}$ Estas obligaciones se regulan por el derecho internacional; que se integra por acuerdos, costumbre internacional y principios generalmente aceptados por las naciones. En el ámbito multilateral se nutre de los acuerdos a los que lleguen los estados en ejercicio de su soberanía y en el marco de los organismos internacionales. ${ }^{4}$ México ha signado más de dos mil instrumentos internacionales; tan sólo en materia de derechos humanos contamos casi medio centenar; dentro de ellos destaca la Convención Americana que establece la aptitud de los estados suscriptores de sujetarse a la jurisdicción de la Corte Interamericana. México signó la Convención Americana el 24 de marzo de 1981 y aceptó la jurisdicción de la Corte el 16 de diciembre de1998; consecuentemente, aquélla le obliga y quedó sometido a esta última.

\footnotetext{
3 Sepúlveda, César, Derecho internacional público, 2a. ed., México, Porrúa, 1964, p. 82.

4 López Bassols, Hermilo, Derecho internacional público contemporáneo e instrumentos básicos, México, Porrúa, 2003, p. 55.
} 


\section{TRATADOS SOBRE DERECHOS HUMANOS}

Salvo los temas en los cuales formuló reserva, México quedó obligado al puntual cumplimiento de las disposiciones de la Convención Americana. Su ámbito de protección complementa el orden interno; si no fuere así ¿qué razones habría para haberla adoptado? Consecuentemente, ante diferendos entre las obligaciones pactadas en este instrumento y las contenidas en la Constitución en materia de tutela de derechos humanos deben privilegiarse las del tratado, pues amplía las contenidas en la carta fundamental. Utilizo un ejemplo sencillo para ilustrar esta complementariedad: el artículo 17 de la Constitución establece como atributos de la jurisdicción que el servicio de justicia debe brindarse de forma pronta, completa, imparcial y gratuita por tribunales que estarán siempre expeditos (libres de trabas) dotados de independencia y autonomía. En tanto el artículo 25 de la Convención Americana establece el derecho de toda persona de contar con un recurso sencillo, rápido y efectivo ante los jueces y tribunales competentes contra actos que violen sus derechos fundamentales. Pero no es lo mismo contar con un recurso para la tutela de los derechos humanos, a que dicho recurso quede al alcance de cualquier gobernado y sea efectivo para su tutela: que su ejercicio esté libre de obstáculos y cumpla con el fin para el que fue diseñado. $Y$ es que diversas restricciones de índole procesal o económica llegan a desnaturalizar la eficacia de cualquier recurso debido a su complejidad o elevado costo. En otros casos no se cuenta con medios de impugnación de índole jurisdiccional en ciertas materias. Esta situación se presentó en México respecto de los derechos políticos, pues, hasta 1977, no se contaba con medios de contradicción que no fueran los radicados en sede política, los que habían demostrado su obsolescencia en un sistema de partido hegemónico. La situación varió por una condena de la Corte Interamericana que ordenó modificaciones a la legislación secundaria para introducir un medio de defensa a fin de impugnar violaciones. Sobre el particular resulta aplicable lo expuesto por la Corte Interamericana en la opinión consultiva solicitada por la Comisión Americana el 10 de agosto de 1990, donde se expresa que la Convención Americana obliga a los estados a respetar los derechos y libertades reconocidos en ella además de garantizar su libre y pleno ejercicio a toda persona sujeta a su jurisdicción. A tal fin, deben tomarse las medidas necesarias para remover los obstáculos que posibiliten que los individuos disfruten de los derechos que en ella se reconocen: "La tolerancia del Estado a circunstancias o condiciones que impidan a los 
individuos acceder a los recursos internos adecuados para proteger sus derechos constituye una violación del artículo 1.1 de la Convención". 5

Hoy día, en una tendencia que tiende a universalizar el contenido y la protección de los derechos humanos, las decisiones de la Corte Interamericana y de otros tribunales como la Corte Europea de Derechos Humanos suelen sobreponerse a las decisiones soberanas expresadas por cualquier Estado al suscribir una obligación internacional cuando se trata de lograr su eficacia; es el caso de las reservas, que en la actualidad deben analizarse bajo óptica diversa a la tradicional, pues, en algunos fallos, La Corte Interamericana ha declarado su invalidez, como ocurrió respecto de la formulada por el Estado mexicano al artículo IX de la Convención sobre Desaparición Forzada de Personas. ${ }^{6}$ La justificación: con ella se negaría la posibilidad de castigar a los responsables de este tipo de delitos considerados crímenes contra la humanidad, ${ }^{7}$ una violación múltiple y continuada de numerosos derechos, lo que le quitaría al tratado la aptitud de conseguir sus fines: "la necesidad de asegurar que este tipo de casos sean investigados ante las instancias competentes de conformidad con las obligaciones internacionales, trasciende los intereses de los Estados". ${ }^{8}$

5 Corte IDH, Opinión Consultiva OC-11/90, del 10 de agosto de 1990, Excepciones al agotamiento de los recursos Internos (art. 46.1, 46.2.a y 46.2.b), Serie A, núm. 11, párrafo 34, solicitada por la Comisión Interamericana de Derechos Humanos, http://www. corteidh.or.cr/docs/opiniones/seriea_11_esp.pdf.

6 Suprema Corte de Justicia de la Nación, Ejecutorias de Pleno, 1 de agosto de 2004 (Caso Sentencia ejecutoria de Pleno, Controversia Constitucional 33/2002), resultando sexto, 9. La reserva de México se sustentó en que la Constitución prevé el fuero de guerra en el artículo 13 y el artículo IX de la Convención estipula que los presuntos responsables de los hechos constitutivos del delito de desaparición forzada de personas sólo podrán ser juzgados por las jurisdicciones de derecho común competentes en cada Estado y excluye la jurisdicción militar, http://suprema-corte.vlex.com.mx/vid/ejecutoria-controversiaconstitucional-26824698.

7 Ambos, Kai (coord.), Análisis comparado e internacional, Alemania, GTZ-Embajada de la República Federal Alemana-Fiscalía General de la Nación-Temis, S.A.-GëorgAugust-Universitát, 2009, p. 245.

8 Corte IDH, Caso Radilla Pacheco vs. México, Excepciones Preliminares, Fondo, Reparaciones y Costas. Sentencia del 23 de noviembre de 2009, Serie C, núm. 209, párrafo 114. 


\section{JERARQUÍA DE LOS TRATADOS DE DERECHOS HUMANOS}

En el ámbito internacional existe consenso en la primacía del derecho internacional público respecto del derecho interno; ${ }^{9}$ preeminencia que deriva del hecho de que el Estado queda obligado por aquél, sea contractual o consuetudinario. ${ }^{10}$ La práctica y la jurisprudencia internacional han reconocido plenamente su supremacía ${ }^{11}$ En consonancia, diversas constituciones de países europeos y algunas de la región sostienen que las obligaciones pactadas en los tratados son parte del derecho federal y crean directamente derechos y deberes para los gobernados y estados. En cuanto a este rubro del análisis, la aparente subordinación del derecho interno (la Constitución) al derecho internacional (el tratado) no necesariamente implica la supremacía de este último respecto de aquélla. Si se trata de aplicar un tratado en materia de derechos humanos ni siquiera resulta relevante determinar si sus mandatos son previos o posteriores a la Constitución. ¡Me explico! Si una disposición contenida en un tratado amplía un derecho de libertad y con posterioridad, ya dentro de su vigencia, una modificación a la Constitución lo restringe, el Estado estaría faltando al compromiso que suscribió en ejercicio de su soberanía. Si la ratificación del tratado fuere posterior al precepto restrictivo constitucional, entonces el Estado quedó comprometido a aplicar las nuevas reglas que confieren mayor amplitud a los derechos de libertad. Estos cuestionamientos quedaron superados con la reforma que elevó la jerarquía de los tratados en el orden interno, los que ahora gozan de rango máximo de protección, y éstos, aun presuponiendo una aparente colisión con otras disposiciones de la carta constitucional, deben interpretarse bajo el principio pro homine (vehículo de interpretación e integración) favoreciendo en todo

9 Díez Velasco, Manuel de (coord.) Instituciones de derecho internacional público, 16a. ed., Madrid, Tecnos, p. 242. Subsisten dos corrientes doctrinales para situar las relaciones entre el ordenamiento jurídico interno y el ordenamiento jurídico internacional. Una sostiene que son dos órdenes jurídicos diferentes y separados en cuanto al proceso de formación. Otra, que coexisten en un solo sistema, pues hay unidad en el ordenamiento jurídico. Para aquella a fin de que un tratado sea aplicable en el orden interno debe transformarse en norma interna mediante un acto del legislativo; la otra, hasta en tanto sean conformes con la norma superior.

${ }^{10}$ Cfr. Álvarez Vita, Juan, Tratados internacionales y ley interna, Perú, Universidad de Lima, Fondo de Desarrollo Editorial-Fondo de Cultura Económica, p. 77.

11 Ibidem. p. 78. 
tiempo la protección más amplia de la persona humana para lograr el fin último que motiva la incorporación de un espacio de libertades protegido en el orden jurídico local: su plena eficacia.

Si los tratados se incorporan al sistema jurídico con rango constitucional no podrán tildarse de inconstitucionales, al menos aquellos que contengan disposiciones relativas a derechos humanos; sin embargo, tenemos el caso de Venezuela, donde la jerarquía constitucional del tratado no impidió problemas relacionados con su aplicación e interpretación, lo que derivó en la negativa de su máximo tribunal para que el Estado cumpliera la condena impuesta por la Corte Interamericana, al estimar que hacerlo violentaría su constitución y motivó su amenaza de renunciar el Sistema Interamericano de Protección a los Derechos Humanos.

Pero ¿qué pasará hoy en nuestro ámbito con la nueva jerarquía del tratado? Con la sola decisión del Ejecutivo y del Senado quedan elevados a rango constitucional y la Suprema Corte ha sostenido que la Constitución no puede tildarse de inconstitucional; aunque cabe advertir que tiempo atrás, con apoyo en la Convención Americana, admitió un juicio de amparo por el que se controvertía la inconstitucionalidad de la propia Constitución por la probable afectación de los derechos humanos, debido a una reforma que se estimaba un retroceso en su protección, ${ }^{12}$ lo que posibilitó la viabilidad del mecanismo de defensa con apoyo en el artículo 25 de la Convención Americana. Resultó puntual que la Suprema Corte determinara la admisión del recurso con apoyo en un tratado; si bien negó su procedencia en cuanto al fondo al reiterar que: "El juicio de amparo, según su regulación actual, no es el conducto adecuado para ese fin". ${ }^{13}$ Entonces, de forma implícita, reconoció que el tratado internacional sí lo era; estuviere o no elevado a rango constitucional, por virtud de su subsidiariedad.

12 La modificación incidió en el artículo 41, fracción III, apartado A, g), párrafo tercero, que prohíbe a cualquier persona contratar propaganda en radio y revisión, lo que si bien limita el ejercicio de un derecho político, los quejosos estimaron que también restringía la libertad de expresión (derecho humano) regulada por el artículo 6o. constitucional, Diario Oficial de la Federación del 13 de noviembre de 2007.

13 Grupo Informativo Contexto, "Corte niega amparo a intelectuales contra ley electoral", México, 28 de marzo de 2011, http://www.grupocontexto.com/2011/03/28/corteniega-amparo-a-intelectuales-contra-ley-electoral/. 


\section{SUBSIDIARIEDAD DE LA CONVENCIÓN AMERICANA SOBRE DERECHOS HUMANOS}

Cualquier Estado que forme parte del Sistema Interamericano de Derechos Humanos está obligado a observar los derechos fundamentales en su ámbito interno; brindar puntual cumplimiento a las disposiciones contenidas en la Convención Americana y además debe acatar el conjunto de valores, principios y derechos reconocidos en éste y otros instrumentos internacionales que amplían la esfera de libertades de los gobernados, cuyo compromiso asumió; no sólo ante la comunidad internacional, sino frente a sus gobernados. ${ }^{14} \mathrm{El}$ ejercicio del poder público en todo Estado constitucional de derecho no se justifica fuera de esta lógica. Estos valores y principios quedan sujetos a la interpretación de la Corte Interamericana al fallar los casos concretos y se recogen en su jurisprudencia firme; tal y como lo ha expresado en opiniones consultivas. ${ }^{15}$

La Convención Americana busca perfeccionar el derecho interno de los estados parte para maximizar la protección que consagra; ello se desprende de su preámbulo, que puede utilizarse para interpretar sus disposiciones acorde con criterios de la Corte Internacional de Justicia. ${ }^{16}$ El preámbulo justifica la ampliación de las normas de protección sobre derechos económicos, sociales y educacionales reconocidas en la Declaración Universal de los Derechos Humanos de 1948, de la Organización de Naciones Unidas, y determina la estructura, competencia y procedimiento de los órganos encargados de esa materia a fin de hacer posible la realización del "ideal del ser humano libre, exento del temor y de la miseria". 17 Se asevera que con este propósito se necesita la revisión o revocación de leyes nacionales que no estén conformes con sus estándares de protección, pues, “en el derecho de gentes, una norma consuetudinaria prescribe que un Estado que ha cele-

14 Corte IDH, Caso Cabrera García y Montiel Flores vs. México, Sentencia del 26 de noviembre de 2010 (Excepción Preliminar, Fondo, Reparaciones y Costas), Voto razonado del juez ad hoc, Eduardo Ferrer Mac Gregor Poisot, http://www.corteidh.or.cr/ docs/casos/articulos/seriec_220_esp.pdf.

15 Corte IDH, "Otros Tratados", Objeto de la Función Consultiva de la Corte (artículo 64 Convención Americana sobre Derechos Humanos), Opinión Consultiva OC-1/82 del 24 de septiembre de 1982. Serie A, núm. 1.

16 Palacios Treviño, Jesús, Tratados. Legislación y práctica en México, 3a. ed., México, Secretaría de Relaciones Exteriores, 2001, p. 112.

17 Organización de las Naciones Unidas, Declaración Universal de los Derechos Humanos, http://www.un.org/es/documents/udhr/. 
brado un convenio internacional, debe introducir en su derecho interno las modificaciones necesarias para asegurar la ejecución de las obligaciones asumidas". ${ }^{18} \mathrm{Si}$ ello es así, y no se cumple con esta adecuación, entonces el Estado, una vez firmada la Convención Americana, implícitamente otorga una "carta blanca" a la Corte Interamericana para que con motivo del conocimiento de cada causa pueda ordenar los "ajustes" que estime pertinentes a la legislación doméstica, aun y cuando sus determinaciones no se vinculen de forma directa con la reparación del daño sufrido por la presunta víctima (una objeción que algunos estados condenados han formulado). La Constitución se convierte así en un documento flexible que se irá adaptando paulatinamente según la evolución que los derechos humanos y su protección vayan logrando en el plano internacional; en ello consiste la internacionalización de estos derechos. ${ }^{19}$

Conviene recordar lo que la Corte Interamericana sostuvo sobre la naturaleza de los tratados sobre derechos humanos, en la Opinión Consultiva OC-2/82, del 24 de septiembre de $1982 ; ;^{20}$ su objeto y fin son la protección de los derechos fundamentales de la persona humana, independientemente de su nacionalidad, tanto frente a su propio Estado como frente a los estados contratantes. Al aprobar estos tratados, los estados se someten a un orden legal dentro del cual ellos, por el bien común asumen varias obligaciones, no en relación con otros estados, sino hacia los individuos bajo su jurisdicción: "Los tratados concernientes a esta materia están orientados, más que a establecer un equilibrio de intereses entre Estados, a garantizar el goce de derechos y libertades del ser humano". ${ }^{21}$

18 Corte IDH, Caso Garrido y Baigorria vs. Argentina, Sentencia del 27 de agosto de 1998 (Reparaciones y Costas), párrafo 68.

19 Atienza, Manuel, Introducción al derecho, 7a. ed., Barcelona, Fontamara, 2011, p. 151, La internacionalización de los derechos fundamentales; derechos humanos reconocidos en las normas de un sistema positivo, parte de la idea de que estos subsisten aun allí donde la legislación no los reconoce. Que tienen vigencia, incluso ahí donde se carece de instrumentos jurídicos y políticos para hacerlos cumplir, pues son derechos para todos: derechos de las personas en su conjunto y de cada uno aislado.

${ }^{20}$ Corte, IDH, El efecto de las reservas sobre la entrada en vigencia de la Convención Americana sobre Derechos Humanos (artículos 74 y 75), Opinión Consultiva OC-2/82, del 24 de septiembre de 1982, Serie A, núm. 2 (1982), párrafo 29.

21 Corte IDH, Opinión Consultiva OC-1/82, del 24 de septiembre de 1982, “Otros tratados", Objeto de la función consultiva de la Corte (artículo 64 Convención Americana Sobre Derechos Humanos), solicitada por el Perú, párrafo 24. 
Acorde con las nuevas tendencias de interpretación de los tratados, si se asumieron obligaciones, las mismas deben cumplirse, aun a costa de adecuar los respectivos ordenamientos jurídicos internos a las nuevas realidades; no obstante que ello implique un "resquebrajamiento" de los criterios tradicionales en torno al concepto de soberanía (y rigidez de la Constitución). ${ }^{22}$ El Estado mexicano quedó situado ante esta disyuntiva con las sentencias de la Corte Interamericana en su contra por violaciones a los derechos humanos y ha optado por la adecuación normativa y el ajuste de criterios jurisprudenciales tradicionales, si bien no las ha cumplido de forma satisfactoria en su integralidad.

La elevación a rango constitucional de los tratados que contienen disposiciones atinentes a derechos humanos implica sólo el primer paso de un proceso que no se puede detener. La nueva orientación del control que plantea su aplicación directa de forma preferente respecto de otras disposiciones del derecho interno evitará condenas contra el Estado, pero resulta de mayor importancia pensar, de una buena vez, en el respeto pleno de la persona humana y de su espacio vital.

\section{OBLIGACIONES DEL ESTADO MEXICANO}

Las estipulaciones de la Convención Americana se aplican en vía de socorro o subsidio en favor de cualquier persona que estime violentados sus derechos fundamentales. Si el Estado mexicano signa y ratifica un tratado lo hace a partir de las disposiciones de su carta fundamental y porque como ente soberano desea asumir diferentes o mayores compromisos de índole protectora. Por ello, el derecho contenido en el tratado resulta necesariamente subsidiario del local: lo complementa (lo mejora). El Diccionario de la Lengua Española define el derecho subsidiario como "aquél que se aplica en defecto de otra norma", ${ }^{23}$ a fin de complementarla, más que para substituirla. Y si lo perfecciona, no puede quedar ubicado con rango inferior, sino análogo o incluso jerárquicamente superior. Así, sus disposiciones de mayor amplitud protectora se utilizan para complementar las deficiencias de la normatividad interna — pues se incorporan a

22 Álvarez Vita, Juan, op. cit, nota 10, p. 34.

23 Real Academia Española, Diccionario de la lengua, http://www.rae.es/rae.html. 
ella y gozan de igual jerarquía-,${ }^{24} \mathrm{o}$ bien se recurre a ellas ante defectos habidos en la actuación de la autoridad estatal por actos u omisiones en la protección de los derechos humanos, pero referidos sólo al caso concreto: al individuo u organización que acudió ante su jurisdicción, pues la Corte Interamericana no realiza un análisis abstracto de la cuestión sometida a su competencia, sino a partir de afectaciones al derecho humano; ésta es otra tendencia de la jurisdicción trasnacional que tiende a desplegarse. Lo anterior conviene tenerlo presente, pues otra corriente de pensamiento sostiene que no pueden utilizarse las disposiciones del tratado para sustituir la normatividad interna. Entenderlo así implicaría que el Estado habría otorgado un amplio aval a la Corte Interamericana para modificar su derecho interno, y conferirle tales facultades, en el caso de México, no queda al alcance del presidente de la República ni del Senado ni es propio del sometimiento a ninguna jurisdicción, mucho menos de aquella donde uno de los sujetos en el diferendo es un Estado soberano. Si bien la subsidiaridad, referida a la tutela de los derechos humanos, significa que la persona, dada su dignidad y fines trascendentales requiere que se les posibilite su pleno desarrollo. Por ello, todo Estado está obligado a orientar las políticas públicas a fin de propiciar la igualdad de oportunidades y brindar tutela a los gobernados; ${ }^{25}$ incluso en contra de sus propias estructuras y agentes. Bajo esta perspectiva, algunos jueces sostienen que "la Convención Americana y otros tratados de derechos humanos fueron concebidos y adoptados con base en la premisa de que los ordenamientos jurídicos internos deben armonizarse con las disposiciones convencionales, y no viceversa" ${ }^{26}$ Por tanto, no se puede esperar que dichas disposiciones convencionales se adapten o se subordinen a las

24 Sánchez-Cordero, Olga, La Constitución y los tratados internacionales. Un acercamiento a la interpretación judicial, México, Poder Judicial del Estado de Sinaloa, Supremo Tribunal de Justicia, 1999, pp. 29-34, La ministra sostiene que la Constitución sigue de manera excepcional el sistema de reenvío e incorporación a normas internacionales en determinadas materias, por lo que dicha normatividad queda comprendida en ella y, por ende, adquiere similar jerarquía, por ello cualquier conflicto que se suscitara entre las normas internacionales y normas de derecho interno tendría que resolverse en favor de las primeras.

${ }^{25}$ Cfr. Adame Godard, Jorge, Diccionario jurídico mexicano, 2a. ed., México, Porrúa-UNAM, Instituto de Investigaciones Jurídicas, 1998, t. P-Z, pp. 3005 y 3006.

${ }^{26}$ Corte IDH, Caso "La Última Tentación de Cristo" (Olmedo Bustos y otros) vs. Chile, Sentencia del 5 de febrero de 2001 (Fondo, Reparaciones y Costas), Voto concurrente del juez Antônio Augusto Cançado Trindade, párrafo 4. 
soluciones de derecho constitucional o de derecho público interno que varían de país a país, sino al contrario.

\section{JURISDICCIÓN DE LA CORTE INTERAMERICANA}

La Corte Interamericana es una institución jurisdiccional que forma parte del Sistema Interamericano de Derechos Humanos para la protección de las prerrogativas reconocidas en los diversos instrumentos internacionales: civiles y políticos. ${ }^{27}$ En el desarrollo de sus atribuciones se sujeta a un Estatuto (O.A.S. Res. 448-IX-0/79, en vigor desde el 1o. de enero de 1980) 28 $^{28}$ y dicta sus propias normas procesales; un tema cuestionado por algunos estados miembros de la Organización de los Estados Americanos (OEA). Sus actividades se rigen por un reglamento aprobado en el periodo ordinario de sesiones LXXXV del 28 de noviembre del 2009. ${ }^{29}$ Como órgano jurisdiccional que debe pronunciar el derecho en los casos concretos sometidos a su conocimiento se apoya en la propia Convención Americana que rige su ámbito competencial y en el derecho internacional público.

Una vez aceptada su jurisdicción tiene competencia para conocer de cualquier caso relativo a la interpretación y aplicación de las disposiciones de la Convención Americana. Sus atribuciones son de índole consultiva y contenciosa (artículos 61, 62 y 63 de la Convención y artículo 2o. del Estatuto). A tal fin formula opiniones a solicitud de los estados miembros u órganos de la OEA respecto de la interpretación de la Convención Americana o de otros tratados protectores de derechos humanos y acerca de la compatibilidad entre los instrumentos internacionales en materia de protección y las leyes internas de un Estado. Esta función consultiva se sujeta a ciertos límites determinados por el propio tribunal: ${ }^{30}$ sólo puede conocer

27 García Ramírez, Sergio y Toro Huerta, Mauricio del, México y la Corte Interamericana de Derechos Humanos. Veinticinco años de jurisprudencia, http://www.bibliojuri dica.org/libros/6/2607/4.pdf.

28 OEA, Estatuto de la Corte Interamericana de Derechos Humanos, http://wwwl. umn.edu/humanrts/oasinstr/szoas6cts.html.

${ }^{29}$ Corte IDH, Reglamento de la Corte Interamericana de Derechos Humanos, http:// www.corteidh.or.cr/reglamento.cfm.

30 Corte IDH, Opinión Consultiva 1, "Otros tratados" objeto de la función consultiva de la Corte (artículo 64 Convención Americana sobre Derechos Humanos), Opinión Consultiva OC-1/82 del 24 de septiembre de 1982, Corte IDH. (Serie A) No. 1 (1982), http:// www.derhumanos.com.ar/opiniones\%20consultivas/opinion\%20consultiva\%2001.htm. 
sobre la interpretación de tratados en que esté directamente implicada la protección de los derechos humanos en un Estado miembro del Sistema Interamericano; resulta inadmisible toda solicitud que conduzca a desvirtuar su jurisdicción contenciosa o debilitar o alterar el sistema o que incida en el menoscabo de los derechos de las víctimas de eventuales violaciones de los derechos humanos; debe considerar las circunstancias de cada caso, $\mathrm{y}$, si concluye que no es posible emitir su opinión, sin violentar sus límites y desnaturalizar su función consultiva, se abstiene de darla.

Su función jurisdiccional, como toda actividad de orden público, debe sujetarse a límites precisos y exige competencia estricta. Si la actuación consultiva tiene limitaciones, pese a que las opiniones no son vinculantes, con mayor razón las tendrá su competencia jurisdiccional dotada de imperium. ${ }^{31}$ El acceso a ésta se restringe a los estados que hayan aceptado su jurisdicción, lo que se realiza en el momento del depósito de la ratificación o adhesión o en cualquier momento posterior.

Dado que su participación como órgano de protección de los derechos humanos es de naturaleza coadyuvante o complementaria de la que ofrece el derecho nacional, sus procedimientos se sujetan a diversos principios como la definitividad del acto ante la jurisdicción estatal: "Que se hayan interpuesto y agotado los recursos de jurisdicción interna, conforme a los principios del derecho internacional generalmente reconocidos". ${ }^{32}$ No tiene caracteres de tribunal de apelaciones, pues no puede revisar las sentencias o decisiones de las autoridades nacionales, a menos que haya irregularidades dentro del proceso o se estimen habidas violaciones a los derechos humanos. Cualquier persona, grupo o entidad no gubernamental legalmente reconocida en uno o más estados miembros de la OEA pueden presentar peticiones, denuncias o quejas por violaciones cometidas por algún otro miembro. Éstas se presentan ante la Comisión Interamericana de Derechos Humanos (Comisión Interamericana), órgano intermedio que decide qué asuntos llegan al procedimiento contencioso de la Corte Interamericana, y una vez en ésta, la víctima, familiares o sus representantes tienen derecho

31 Corte IDH, Opinión Consultiva 1. "Otros tratados" objeto de la función consultiva de la Corte (art. 64 Convención Americana sobre Derechos Humanos), Opinión Consultiva OC-1/82 del 24 de septiembre de 1982, Corte I.D H. (Serie A) No. 1 (1982), http:// www.derhumanos.com.ar/opiniones\%20consultivas/opinion\%20consultiva\%2001.htm.

32 Corte IDH, Convención Americana sobre Derechos Humanos, San José de Costa Rica, 22 de noviembre de 1969, Conferencia Especializada Interamericana sobre Derechos Humanos, http://www.cidh.org/basicos/basicos2.htm. 
a participar en el juicio; aunque no siempre ha sido de este modo, pues las reglas inherentes a la capacidad procesal de la persona para demandar la efectividad de un tratado que establece prerrogativas en su favor también se están transformando, pues ni los derechos humanos ni su defensa pueden quedar subordinados a la decisión de los estados u organismos internacionales debido a su preeminencia.

\section{ALCANCE DE SUS SENTENCIAS}

Los estados parte se comprometen a cumplir sus resoluciones, pues tienen carácter definitivo e inapelable. Si el tribunal decide que hubo violación de un derecho o libertad protegidos dispone que se garantice al lesionado en su goce. También puede determinar la reparación de las consecuencias de la medida o situación que ha configurado la vulneración de los derechos y el pago de indemnizaciones o reparaciones. Dentro de aquellas susceptibles de satisfacerse a las víctimas o sus familiares destacan algunas que se han determinado recientemente en contra del Estado mexicano: garantía actual y futura que repara la inseguridad y la vulnerabilidad resultante de la violación cometida; indemnización por daños material y moral (integridad de la indemnización, costas procesales y lucro cesante); daño al proyecto de vida (lo que el ser humano ha decidido ser y hacer en su vida o lo que hace para ser), ${ }^{33}$ que se compensa con una compensación en numerario; medidas de derecho interno contra actos de cualquier autoridad, por ejemplo, que no se modifique el estatus quo del asunto sometido a la jurisdicción así como la protección de la vida y la integridad física de la presunta víctima o de sus familiares y otras satisfacciones de carácter honorífico, como la construcción de memoriales en honor de las víctimas, ${ }^{34}$ otro tema cuestionado.

Sin embargo, dada la naturaleza subsidiaria de las disposiciones contenidas en la Convención Americana así como de la Corte Interamericana como tribunal de equidad, ésta complementa sus decisiones con fuentes no

33 Cfr. Fernández Sessarego, Carlos, "Deslinde conceptual entre "daño a la persona", "daño al proyecto de vida" y "daño moral, http://www.pucp.edu.pe/. La jurisprudencia lo refiere una potencialidad actuante que permite decidir, elegir, entre muchas oportunidades o posibilidades de vida: la suma de quehaceres en el tiempo.

34 Corte IDH, Caso González y Otras ("Campo algodonero") vs. México, Sentencia del 16 de noviembre de 2009, excepción preliminar, fondo, reparaciones y costas y caso Radilla Pacheco vs. México. Excepciones preliminares, fondo, reparaciones y costas, sentencia del 23 de noviembre de 2009, Serie c, núm. 209. 
escritas; como la jurisprudencia y los principios generales de derecho que observa toda nación civilizada ante insuficiencias que le permitan colmar lagunas jurídicas, ${ }^{35}$ pues rige su actuación bajo el principio de plenitud hermenéutica que presupone que el orden jurídico constituye un todo normativo: "Un sistema continuo en el que no caben lagunas, fisuras o fallas que impidan regular necesaria y totalmente desde el punto de vista jurídico cualquier conflicto". ${ }^{36}$ Debido a ello, además de las condenas por daño material e inmaterial que posibilitan el restablecimiento del derecho y la reparación de los daños producidos por violaciones, en jurisprudencia firme ha sostenido el deber de los estados de prevenir, investigar y sancionar toda violación de los derechos reconocidos por la Convención Americana así como la obligación de construir un orden normativo dirigido a hacer posible el cumplimiento de las obligaciones en la materia; ${ }^{37}$ por eso exige que la conducta gubernamental se despliegue con amplitud para asegurar la eficacia de los derechos humanos.

El Estado queda obligado a cumplir todas y cada una de las prestaciones a que se le condene y dentro de los plazos fijados en los propios fallos; pero resulta pertinente formular algunas preguntas que ya han sido hechas en otras latitudes: ¿también debe cumplirlas si los fallos de la Corte Interamericana excedieren su competencia y atribuciones y en ellos planteara determinaciones, no de naturaleza subsidiaria, sino esencial, que se estimaran atentatorias de la soberanía del Estado? ¿Está obligado el Estado condenado a acatar cualesquier resolución, más allá de los compromisos signados? Sobre este tópico, la Corte Internacional de Justicia de las Naciones Unidas ha sostenido de forma constante que el derecho interno no puede prevalecer ni sobre las obligaciones de un Estado según el derecho internacional consuetudinario ni sobre sus obligaciones según el derecho internacional convencional $\mathrm{y}$, como consecuencia, no

35 "Las fuentes no escritas del derecho europeo: el derecho subsidiario", http://eu ropa.eu/legislation_summaries/institutional_affairs/decisionmaking_process/l14533 es.htm.

36 Calvo, Julián, "La plenitud del ordenamiento jurídico-penal", Revista de la Facultad de Derecho de México, México, núm. 15, julio-septiembre de 1954, p. 16, http://www. juridicas.unam.mx/publica/librev/rev/facdermx/cont/15/dtr/dtr2.pdf.

37 Cfr. Corte IDH, Caso Velásquez Rodríguez vs. Honduras. Excepciones Preliminares, Sentencia del 26 de junio de 1987, Serie C, núm. 1 y Caso Godínez Cruz vs. Honduras. Excepciones Preliminares. Sentencia del 26 de junio de 1987, Serie C, núm. 3, y Sentencia del 20 de enero de 1989, párrafo 175. 
puede invocar frente a otro Estado su propia Constitución con la finalidad de sustraerse del cumplimiento de las obligaciones que le impone el derecho internacional y los tratados en vigor. ${ }^{38}$ Ésta es la tendencia de la jurisdicción internacional, pero, los derechos y obligaciones que regula el derecho internacional, según interpretación de la Corte Interamericana, van más allá de los que el Estado aceptó espontáneamente en ejercicio de su soberanía; debido a ello incluso ha tenido por no puestas algunas reservas. Si bien podemos compartir este nuevo enfoque en las relaciones internacionales y en la disciplina científica que las rige o cuestionar la legitimidad de lo resuelto en cada caso bajo criterios tradicionales, resulta innegable que el Estado está obligado a su cumplimiento aun y cuando considere excesivos los términos del fallo en tanto lo ligue la vigencia del tratado y la obligatoriedad de la jurisdicción "trasnacional" por tratarse de una decisión que no puede ser cuestionada jurídicamente.

Más aún, a ningún Estado o persona le conviene deslegitimar las atribuciones y actuación de la Corte Interamericana. El mismo derecho internacional nos señala la pauta a seguir: cumplir lo fallado y posteriormente denunciar el tratado si no se está en aptitud de responder a las obligaciones asumidas o si las condenas se estimaren pronunciadas con deficiente sustento o incluso sin él; pero, como lo afirma Modesto Seara: "Un Estado no puede ordenar su sistema jurídico interno sin tener en cuenta y respetar las normas jurídicas internacionales". ${ }^{39}$ Hoy, no sólo las de libre suscripción, sino incluso otras determinadas por la propia comunidad internacional en materia de protección a los derechos humanos. Agustín Carrillo complementa que este derecho implica limitaciones a la actuación del Estado en el orden doméstico y postula la existencia de una relación íntima y armónica entre el plano internacional y este último: "Dos ámbitos normativos con diferentes campos de aplicación y responsabilidades que cada día se vinculan más entre sí y que atienden a la complejidad de la comunidad internacional y al fenómeno de la globalización". ${ }^{40}$ Este fenómeno de globalización-mundialización de los fenómenos económicos y sociales también ha alcanzado al derecho, refiere Eduardo Ferrer Mac-Gregor: "Lo que ha propiciado el surgimiento

38 Díez de Velasco, Manuel, op. cit., p. 243.

39 Seara Vázquez, Modesto, Derecho internacional público, 22a. ed., México, Porrúa, 2005, p. 51.

40 Maldonado Orozco, Jorge (coord.) Derecho internacional público. Temas selectos para oficiales de la Armada de México, México, Secretaría de Marina, Armada de México, 2010, p. 12. 
de organismos jurisdiccionales supranacionales, en el ámbito regional e internacional, encargados de interpretar y resolver conflictos derivados de los diversos documentos suscritos por los Estados". ${ }^{41}$

Hasta ahora, México está en vías de cumplimiento de las sentencias pronunciadas en este ámbito; si bien algunas de ellas han provocado cuestionamientos en cuanto al alcance de las obligaciones a su cargo así como de los términos de su cumplimiento. En la sentencia atinente al Caso Castañeda Gutman vs. los Estados Unidos Mexicanos (6-VIII-2008)42 se condenó al estado a realizar la adecuación de la legislación secundaria con la finalidad de contar con un mecanismo de defensa para la tutela de los derechos fundamentales de índole política, pues se consideró violado el artículo 25 de la Convención Americana que dispone como obligación de todo Estado, la necesidad de contar con un recurso o medio de impugnación: sencillo, pronto, gratuito y eficaz para la defensa de los derechos humanos (civiles y políticos). Las autoridades estatales negaron a la víctima el registro de su candidatura ciudadana para contender en la elección presidencial y, dado el diseño de la legislación electoral, de los medios de impugnación, así como de los criterios interpretativos de la Suprema Corte de Justicia de la Nación, se le restringió el derecho de impugnar tal negativa bajo términos de eficacia.

La condena de la Corte Interamericana fue puntual, pulcra y atendible, pues, pese a que el artículo 99 de la Constitución mexicana incorporaba un juicio de protección con tal objeto, la jurisprudencia por contradicción del tribunal pleno de la Suprema Corte de Justicia de la Nación P./J.25/200243 había determinado que la única vía para impugnar leyes electorales era la acción de inconstitucionalidad, procedimiento no asequible a los ciudadanos; por tanto, el recurso se tornó ineficaz. A sabiendas de que faltaba a la verdad —o quizá en total desconocimiento del sistema de impugnación electoral-, el representante del Estado manifestó que la reclamación de la víctima resultaba infundada, pues el texto constitucional garantizaba la existencia de un recurso adecuado y eficaz para la atención de sus reclamos, lo cual era y sigue siendo inexacto.

41 Ferrer Mac-Gregor, Eduardo, La Corte Interamericana de Derechos Humanos como intérprete constitucional (dimensión trasnacional del Derecho Procesal Constitucional), p. 214, http://www.bibliojuridica.org/libros/1/94/12.pdf.

42 Corte IDH, "Caso Castañeda Gutman vs. México". Excepciones Preliminares, Fondo, Reparaciones y Costas, Sentencia del 6 de agosto de 2008. Serie C, núm. 184.

43 Tesis, P./J.25/2002, Semanario Judicial de la Federación, t. XV, junio de 2002, p. 81. 
Poco antes de que se dictara sentencia, el Constituyente Permanente reformó el artículo 99 de la Constitución para incorporar la aptitud del Tribunal Electoral del Poder Judicial de la Federación para declarar la no aplicación de leyes electorales. ${ }^{44} \mathrm{El}$ representante del Estado solicitó que se decretara infundada y sin sustancia la petición formulada por la presunta víctima, puesto que en el texto constitucional ya se habían desarrollado atribuciones que posibilitaban la garantía de los derechos electorales y el tribunal competente podía decretar la inaplicación de cualquier precepto legal que se estimare contrario a la carta fundamental; con ello — se adujo - se subsanaba la deficiencia que había provocado la reclamación, pero, aun y cuando la Corte Interamericana valoró positivamente la adecuación y la estimó un paso importante para la solución de la problemática llevada ante su competencia, no consideró que solucionara la cuestión de forma integral, sino hasta en tanto fuera armonizada con la legislación secundaria para lograr los fines que se reclamaban. ${ }^{45}$ La sentencia ordenó que en un plazo razonable se completara la adecuación del derecho interno. En acatamiento se realizaron adecuaciones al artículo 189, fracción I, inciso e de la Ley Orgánica del Poder Judicial de la Federación y artículo 79 de la Ley General del Sistema de Medios de Impugnación en Materia Electoral a fin de dotar al tribunal electoral de atribuciones para conocer y resolver en única instancia y de forma definitiva e inatacable violaciones al derecho de ser votado en las elecciones de presidente de los Estados Unidos Mexicanos; aunque me parece que las adecuaciones realizadas siguen siendo incompletas.

En la sentencia dictada en el caso González y Otras (Campo algodonero) vs. México; ${ }^{46}$ que derivó de la responsabilidad internacional del Estado por la desaparición y ulterior muerte de tres jóvenes mujeres cuyos cuerpos fueron encontrados sin vida en un campo algodonero de Ciudad Juárez se le responsabilizó por la falta de medidas de protección a las víctimas y de prevención de sus crímenes; la falta de respuesta de las autoridades, la indebida diligencia en la investigación de los asesinatos y la denegación de justicia y falta de reparación adecuada. ${ }^{47}$ La condena ordenó estandarizar los protocolos,

44 Constitución Política de los Estados Unidos Mexicanos, Diario Oficial de la Federación, 13 de noviembre de 2007, http://www.diputados.gob.mx/LeyesBiblio/ref/cpeum art.htm.

45 Corte IDH, "Caso Castañeda Gutman vs. México", op. cit.

46 Idem.

47 Corte IDH, Caso González y otras ("Campo algodonero") vs. México, Sentencia del 16 de noviembre de 2009 (Excepción Preliminar, Fondo, Reparaciones y Costas). 
manuales, criterios ministeriales de investigación, servicios periciales y de impartición de justicia utilizados para investigar delitos relacionados con desapariciones, violencia sexual y homicidios de mujeres con el Protocolo de Estambul, el Manual sobre la Prevención e Investigación Efectiva de Ejecuciones Extrajudiciales, Arbitrarias y Sumarias de Naciones Unidas y los estándares internacionales de búsqueda de personas desaparecidas con base en perspectiva de género; implementar programas y cursos permanentes de educación y capacitación en derechos humanos y género y para la debida diligencia en la conducción de averiguaciones previas y procesos judiciales relacionados con discriminación, violencia y homicidios de mujeres dirigidos a funcionarios públicos; conducir eficazmente el proceso necesario para identificar, procesar y sancionar a los responsables de los asesinatos y levantar un monumento en memoria de las víctimas y en la ceremonia respectiva develar una placa donde se reconozca la responsabilidad internacional del Estado por los crímenes.

En el caso Radilla Pacheco vs los Estados Unidos Mexicanos ${ }^{48}$ instaurado con motivo de la desaparición forzada del nacional a manos de elementos del Ejército, la sentencia estableció, entre otras, las obligaciones siguientes: conducir eficazmente la investigación y los procesos penales en relación con la detención y posterior desaparición forzada de la persona; continuar con su búsqueda efectiva y localización inmediata de ella o de sus restos mortales; realizar un acto público de reconocimiento de responsabilidad por los hechos y en desagravio a la memoria de la víctima en el que se hiciera referencia a las violaciones de derechos humanos en presencia de altas autoridades nacionales y familiares y se colocara una placa rememorativa, además de adoptar reformas legislativas para compatibilizar disposiciones del Código de Justicia Militar con los estándares internacionales en la materia y de la Convención Americana para permitir que las personas afectadas por la intervención del fuero militar cuenten con un recurso efectivo de impugnación de tal competencia y para compatibilizar la legislación penal federal con los estándares internacionales en la materia y de la Convención Interamericana sobre desaparición forzada de personas.

La sentencia pronunciada en el caso Fernández Ortega y Otros vs. México $^{49}$ también involucró la actuación de elementos del Ejército en la

48 Idem.

49 Corte IDH, Jurisprudencia, Casos Contenciosos, www.corteidh.or.cr/docs/casos/ articulos/seriec_209_esp.pdf. 
violación de derechos humanos así como fallas del sistema de procuración de justicia. La Corte Interamericana fijó diversas obligaciones; entre ellas: conducir en el fuero ordinario la investigación y el proceso penal por la violación de la víctima con el fin de determinar responsabilidades penales y aplicar sanciones; continuar con el proceso de estandarización de un protocolo de actuación para el ámbito federal y la entidad federativa respecto de la atención e investigación de violaciones sexuales acorde con parámetros del Protocolo de Estambul y en las directrices de la Organización Mundial de la Salud; implementar programas permanentes y obligatorios de capacitación y formación en derechos humanos para los miembros de las fuerzas armadas; otorgar becas de estudios en beneficio de las hijas de la víctima; facilitar recursos para que en la comunidad indígena se establezca un centro comunitario de actividades educativas en derechos humanos y de género; adoptar medidas para que las niñas de la comunidad cuenten con facilidades de alojamiento y alimentación que posibiliten su educación; asegurar los servicios de atención a las mujeres víctimas de violencia sexual, por instituciones dotadas de recursos materiales y personales suficientes, y realizar un acto público de reconocimiento de responsabilidad internacional con relación a los hechos juzgados, además de adoptar reformas legislativas que compatibilicen las disposiciones del Código de Justicia Militar con los estándares internacionales en la materia.

En el caso Rosendo Cantú y Otra vs. México,${ }^{50}$ la Corte Interamericana pronunció sentencia con motivo de violaciones diversas cometidas por elementos del Ejército y condenó al cumplimiento, entre otras, de las obligaciones siguientes: conducir en el fuero ordinario la investigación y el proceso penal las conductas violatorias de los derechos de las víctimas; continuar con el proceso de estandarización de un protocolo de actuación para la atención e investigación de violaciones sexuales acorde con los parámetros establecidos en el Protocolo de Estambul y en las directrices de la Organización Mundial de la Salud; otorgar becas de estudios en beneficio de la víctima y su dependiente; continuar acciones de capacitación en derechos humanos para los integrantes de las fuerzas armadas y campañas de concientización y sensibilización de la población sobre la prohibición y los efectos de la violencia y discriminación; realizar un acto público de reconocimiento de responsabilidad internacional en relación con los

${ }^{50}$ Corte IDH, Jurisprudencia, Casos Contenciosos http://www.corteidh.or.cr/docs/ casos/articulos/seriec_216_esp.pdf. 
hechos y adoptar las reformas pertinentes para permitir que las personas afectadas por la intervención del fuero militar cuenten con un recurso efectivo de impugnación de tal competencia así como reformas legislativas para compatibilizar disposiciones del Código de Justicia Militar con los estándares internacionales en la materia y con la Convención Americana.

En el caso Cabrera García y Montiel Flores vs. México ${ }^{51}$ se pronunció sentencia con motivo de la demanda que alegó responsabilidad del Estado por el sometimiento a tratos crueles, inhumanos y degradantes de las víctimas mientras se encontraban detenidos y bajo custodia de miembros del Ejército; por su falta de presentación ante algún funcionario que controlara la legalidad de la detención y por las irregularidades del proceso penal. En ella se establecieron, entre otras, las obligaciones siguientes: conducir la investigación penal de los hechos para determinar responsabilidades penales y administrativas; otorgar tratamiento médico y psicológico especializado y medicamentos a la víctima; adoptar reformas legislativas para compatibilizar las disposiciones del Código de Justicia Militar con los estándares internacionales en la materia y con la Convención Americana y contar con un recurso para impugnar el fuero militar.

Pueden advertirse las similitudes de las violaciones cometidas en perjuicio de los derechos humanos en las últimas sentencias ilustradas así como la coincidencia de los agresores: miembros de las fuerzas armadas que, en México, desde tiempo atrás, desarrollan tareas de seguridad pública y quedan sujetos a un fuero especial en términos del Código de Justicia Militar, lo que aunado al criterio interpretativo de la Suprema Corte de Justicia de la Nación inhibía juzgarlos por conductas delictivas bajo garantías judiciales de autonomía e independencia, pues se juzgaban por tribunales militares, al tiempo que se contravenía el criterio de la Corte Interamericana: "La jurisdicción penal militar no es el fuero competente para investigar y, en su caso, juzgar y sancionar a los autores de violaciones de derechos humanos sino que el procesamiento de los responsables corresponde siempre a la justicia ordinaria". ${ }^{52}$

51 Corte IDH, Caso Cabrera García y Montiel Flores vs. México, Sentencia del 26 de noviembre de 2010, (Excepción Preliminar, Fondo, Reparaciones y Costas).

52 Corte IDH, Caso Radilla Pacheco vs. Estados Unidos Mexicanos, Sentencia del 23 de noviembre de 2009 (Excepciones Preliminares, Fondo, Reparaciones y Costas), párrafo 273 .

Cfr. Caso de la Masacre de la Rochela vs. Colombia, párrafo 200 y Caso Escué Zapata vs. Colombia, párrafo 105 . 
Para dar los primeros pasos en el cumplimiento de la sentencia del caso Radilla Pacheco el alto tribunal, mediante consulta a trámite formulada en el expediente varios 912/2010 estimó necesario hacer precisiones acerca de los términos de la participación del Poder Judicial de la Federación en cuanto al alcance y modo de acatamiento, "a pesar de que no existe notificación formal", en especial del apartado relativo a la obligatoriedad de la jurisprudencia de la Corte Interamericana para los jueces nacionales.

Tiempo atrás, la Corte Interamericana ya había resuelto la vinculación de sus sentencias para la totalidad de los órganos estaduales; entre ellos los poderes judiciales, pues ejercen una función pública atribuida originariamente al Estado, cuando determinó que "cuando un Estado ha ratificado un tratado internacional como la Convención Americana, sus jueces, como parte del aparato del Estado también están sometidos a ella, lo que les obliga a velar porque los efectos de las disposiciones de la Convención no se vean mermadas por la aplicación de leyes contarías a su objeto y fin". ${ }^{53} \mathrm{El}$ precedente se reiteró poco después en el Caso trabajadores cesados del Congreso (Aguado Alfaro y Otros) vs. Perú, como refiere el juez ad hoc Eduardo Ferrer Mac Gregor-Poisot en su voto razonado en la sentencia pronunciada en el caso Cabrera García y Montiel Flores vs. México: ${ }^{54}$

Este Poder debe ejercer una especie de control de convencionalidad entre las normas jurídicas internas que aplican en los casos concretos y la Convención Americana Sobre Derechos Humanos. En esta tarea, el Poder Judicial debe tener en cuenta no solamente el tratado, sino también la interpretación que del mismo ha hecho la Corte Interamericana, intérprete último de la Convención Americana.

Derivado de la consulta se emitieron diversos criterios interpretativos que dieron un giro al sistema de control constitucional imperante en México, con larga tradición concentrada en sede de órganos del Poder Judicial de la Federación. Ahora, este sistema de control coexistirá con otro incidental o difuso: concentrado en acciones de inconstitucionalidad, controversias constitucionales y amparo directo e indirecto y difuso en todos los procesos

53 Corte IDH, Caso Almonacid Arellano vs. Chile, Sentencia del 26 de septiembre de 2006 (Excepciones Preliminares, Fondo, Reparaciones y Costas), párrafo 124.

54 Corte IDH, Caso Cabrera García y Montiel Flores vs. México, Sentencia del 26 de noviembre de 2010, voto razonado del juez ad hoc Eduardo Ferrer Mac Gregor-Poisot, párrafo 13 . 
ordinarios. ${ }^{55}$ Con tal decisión se dejaron sin efectos las tesis jurisprudenciales números P./J. 73/99 y P./J. 74/99 que establecían que el control judicial de la Constitución es atribución exclusiva del Poder Judicial de la Federación y que el denominado "control difuso" no encuentra sustento en el artículo 133 de la norma suprema. ${ }^{56}$ Los criterios establecen que los jueces no pueden hacer declaraciones generales sobre su invalidez o expulsar del orden jurídico las normas que consideren contrarias a los derechos humanos, pero sí están obligados a dejar de aplicar las normas inferiores dando preferencia a las contenidas en la Constitución y en los tratados en la materia. En tanto, todas las demás autoridades del país, en el ámbito de sus competencias, tienen obligación de aplicar las normas correspondientes acorde con la interpretación más favorable a la persona, para lograr su protección más amplia, sin tener la posibilidad de inaplicar o declarar su incompatibilidad:

a) Los jueces del país deben interpretar el orden jurídico a la luz y conforme a los derechos humanos reconocidos en la Constitución y tratados internacionales en que México sea parte, favoreciendo en todo tiempo a las personas con la protección más amplia.

b) Cuando haya varias interpretaciones jurídicamente válidas debe partirse de la presunción de constitucionalidad de las leyes y preferir aquella que acorde a los derechos humanos reconocidos en la Constitución y en los tratados para evitar incidir o vulnerar el contenido esencial de estos derechos.

c) Determinar la inaplicación de la ley sólo cuando las alternativas anteriores no sean posibles.

Finalmente, la Suprema Corte determinó lo que en el plano internacional era principio de explorado derecho desde tiempo atrás, acorde con las obligaciones contraídas en la Convención Americana y del sometimiento a

55 Tesis P. LXX/2011 (9a.), Semanario Judicial de la Federación y su Gaceta, libro III, diciembre de 2011, p. 557.

56 Tesis: P. LXX/2011 (9a.), Semanario Judicial de la Federación y su Gaceta, Libro III, diciembre de 2011, p. 557; Tesis: P. LXVI/2011 (9a.), Semanario Judicial de la Federación y su Gaceta, Libro III, diciembre de 2011, p. 550, y Tesis: P. LXIX/2011(9a.), Semanario Judicial de la Federación y su Gaceta, Libro III, diciembre de 2011, p. 552. 
la jurisdicción de la Corte Interamericana: que las sentencias pronunciadas por la Corte Interamericana son vinculantes cuando el Estado mexicano fuere parte en el litigio. Debido a ello, las normas relativas a derechos humanos "se interpretarán de acuerdo con lo que ella establece (la Convención Americana) y de conformidad con los tratados internacionales de la materia y favoreciendo en todo tiempo a las personas la protección más amplia". ${ }^{57}$ Respecto de la vigencia del fuero militar impugnado ante la Corte Interamericana, el mismo no podrá operar bajo ninguna circunstancia frente a situaciones que vulneren derechos humanos de civiles.

Las condenas también propiciaron la reforma constitucional en materia de derechos humanos y sus garantías. Ahora, la Constitución mexicana confiere rango de norma suprema a los tratados que contengan disposiciones sobre derechos humanos y se flexibilizaron los principios que rigen al juicio de amparo (6 y 10 de junio de 2011). Si bien las adecuaciones al derecho interno todavía siguen siendo de índole declarativo, pues está pendiente la expedición de la ley reglamentaria del amparo; complementar la reforma al juicio de protección de los derechos político electorales, y, en general, el cumplimiento integral de las demás obligaciones determinadas en contra el Estado mexicano.

\section{LA SENTENCIA CONTRA VENEZUELA}

En fecha reciente, el Estado venezolano decretó desatender un fallo de la Corte Interamericana al estimarlo violatorio de su Constitución. ${ }^{58}$ Ello se produjo con motivo de la destitución de tres jueces de la Corte Primera de lo Contencioso Administrativo por haber incurrido en error judicial inexcusable: Caso Apitz Barbera y otro (Corte Primera de lo Contencioso Administrativo) vs. Venezuela. ${ }^{59} \mathrm{La}$ Comisión Interamericana declaró admisible una reclamación presentada por "las presuntas víctimas" y, debido a que el

57 Expediente “varios" 912/2010, relativo a la instrucción ordenada por el Tribunal Pleno de la Suprema Corte de Justicia de la Nación, en la resolución de fecha siete de septiembre de dos mil diez, dictada dentro del expediente "varios" 489/2010, párrafo 44.

58 Corte Suprema de Justicia, República Bolivariana de Venezuela, Expediente núm. 08-1572, http://es.scribd.com/doc/10450842/Sala-Constitucional.

59 Corte IDH, Caso Apitz Barbera y otros ("Corte de lo Contencioso Administrativo") vs. Venezuela. Excepción Preliminar, Fondo, Reparaciones y Costas, Sentencia del 5 de agosto de 2008, Serie C, núm. 182. 
Estado no adoptó las recomendaciones que le formuló, decidió someterlo a la jurisdicción de la Corte Interamericana. ${ }^{60}$

\section{Argumentos de las partes}

La Comisión Interamericana razonó que la destitución resultaba contraria al principio de independencia judicial, pues atentaba contra la garantía de fallar libremente en derecho. ${ }^{61}$ Desde su perspectiva implicaba una diferencia razonable y razonada de interpretaciones jurídicas posibles sobre una figura procesal. Y toda vez que se depuso a los jueces sin motivación alguna y sin contar con un recurso sencillo, rápido y efectivo para impugnarla, se violó su derecho a un debido proceso. Advirtió que un "conjunto de indicios" permitiría inferir que el órgano que ordenó la destitución carecía de independencia e imparcialidad y que la misma obedeció a una "desviación de poder" a partir de las declaraciones que en contra de los juzgadores depuestos pronunció el presidente de la República. El representante del Estado adujo que las declaraciones no constituyeron tal abuso, pues si "son llevadas a su debido contexto, resulta evidente que fueron realizadas en aras de un interés público que se produjo como consecuencia de una inconfundible necesidad en una sociedad democrática". ${ }^{62}$ Además, debido a que los jueces no habían agotado los mecanismos legales de la jurisdicción interna para impugnar su destitución, incurrían en falta de interés procesal al no haber satisfecho el principio de definitividad para acudir ante la instancia supranacional. ${ }^{63}$ La Comisión alegó que el Estado se refirió por primera vez al tema del agotamiento de los recursos internos de modo extemporáneo, pues no lo hizo valer en la primera oportunidad procesal que tuvo: "En la respuesta a la petición de la Comisión que dio inicio al trámite". Además, tampoco presentó argumentos que justificaran la razonabilidad de la decisión tomada;

60 Venezuela ratificó la Convención Americana el 23 de junio de 1977 y reconoció la jurisdicción de la Corte Interamericana el 24 de junio de 1981, http://www.oas.org/ juridico/spanish/firmas/b-32.html.

61 Corte IDH, véase nota 59.

62 Idem.

${ }^{63}$ Nota: los jueces removidos por resolver en contra de los intereses de la administración pública venezolana, difícilmente tendrían garantías para una debida defensa con la animadversión del Ejecutivo, en un país que ocupa el lugar 172 de 182 en el ranking de honestidad mundial (Corruption perceptions index 2011", en Transparenty international. The global coalition against corruption, http://www.transparency.org/. 
por ello estimó que el proceso disciplinario seguido a los jueces “terminó siendo de mero trámite".

\section{Admisión de la demanda}

La Corte Interamericana reiteró lo aducido por la Comisión: que el Estado no interpuso la excepción preliminar de falta de agotamiento de los recursos internos, sino hasta después del informe de admisibilidad a través de un escrito allegado durante la etapa de fondo.$^{64}$ Desde su óptica, de forma tácita implicó su renuncia a presentar esta defensa en el momento procesal oportuno. En el análisis de fondo, en tanto, estimó que los estados están obligados a asegurar que los jueces provisorios sean independientes y debe otorgárseles cierto tipo de estabilidad y permanencia en el cargo, puesto que la provisionalidad no equivale a libre remoción. Y si bien el Estado ofreció a las víctimas un proceso previo a su destitución, éste no se ajustó a las obligaciones contraídas en términos de la Convención Americana, pues así como todos los órganos que ejercen funciones de naturaleza materialmente jurisdiccional tienen el deber de adoptar decisiones justas basadas en el respeto pleno a las garantías del debido proceso, también cualquier persona tiene derecho a ser oída por un juez o tribunal competente para la determinación de sus derechos cuando alguna autoridad pública, no judicial, dicte resoluciones que los afecten; ${ }^{65}$ caso que no ocurrió tratándose de los jueces removidos.

\section{La sentencia}

La Corte Interamericana consideró que el Estado incumplió su deber de motivar la destitución: no garantizó el derecho de las “víctimas" a ser juzgadas por un tribunal imparcial e independiente; violó su derecho a ser oídas dentro de un plazo razonable; incumplió el deber de motivación derivado de las debidas garantías y el derecho de contar con un recurso sencillo, rápido y efectivo para la defensa de sus derechos (artículos 1.1, 8.1 y 25.1 de la Convención Americana); por ello dictó sentencia condenatoria por concepto

64 Corte IDH, Escrito del Estado de 28 de julio de 2005, recibido por la Comisión el 10. de agosto de 2005 (Expediente de prueba), t. II, folios 661-665.

65 Corte IDH, Caso Yatama vs. Nicaragua (Excepciones Preliminares, Fondo, Reparaciones y Costas), Sentencia del 23 de junio de 2005, Serie C, núm. 127, párrafo 149. 
de daño material e inmaterial, costas y gastos y ordenó la reincorporación de los jueces destituidos, si lo desearen. Si ello no fuere posible o no lo quisieren, entonces se pagaría a cada uno la indemnización correspondiente. Adicionalmente deberían adoptarse medidas para la aprobación del Código de Ética del Juez y la Jueza venezolanos, en el plazo de un año.

\section{ACCIÓN DE CONTROL DE CONSTITUCIONALIDAD}

El Estado interpuso una Acción de Control de Constitucionalidad ante su Corte Suprema una vez que se le notificó la sentencia, a fin de que se interpretara su conformidad con la constitución de la República, en la cual demandó su inejecutabilidad por contravenirla. ${ }^{66}$ Vale subrayar lo indicativo de la promoción: que se interprete la sentencia en determinado sentido para no acatarla. La Sala Constitucional justificó su competencia en su carácter de garante de la supremacía y principios constitucionales. Seguidamente, refiriéndose a la ejecución de la decisión de la Corte Interamericana, alegó que sus fallos "no son de obligatorio cumplimiento y no son aplicables si violan la Constitución o no se hayan agotado los recursos judiciales internos. Lo contrario sería subvertir el orden constitucional y atentaría contra la soberanía del Estado". ${ }^{67}$ Argumentó que se vulneraba la supremacía de la constitución y que el cumplimiento del fallo violentaría el principio de autonomía del poder judicial, pues llama al desconocimiento de los procedimientos legalmente establecidos para la toma de medidas y sanciones contra actuaciones de jueces que contraríen su deber (¿qué existe un deber del juez de resolver en determinado sentido la causa que se somete a su conocimiento?). Se resaltó, además, que "la sentencia de manera ligera dispone que los accionantes no fueron juzgados por un juez imparcial", ${ }^{68}$ no obstante que la propia Corte señaló que no fue debidamente comprobada tal parcialidad, y que por el supuesto hecho de no existir un procedimiento idóneo previsto en el ordenamiento jurídico interno, para investigar y sancionar la conducta denunciada por los jueces, se concluya que no incurrieron en motivo alguno que justificare su destitución. En síntesis, el Estado denunció la intromisión de la Corte Interamericana en su ámbito interno al desconocer

${ }^{66}$ Corte Suprema de Justicia, República Bolivariana de Venezuela, Expediente núm. 08-1572, http://es.scribd.com/doc/10450842/Sala-Constitucional.

67 Idem.

68 Idem. 
el ordenamiento jurídico en cuanto al establecimiento de medidas y sanciones contra los miembros del poder judicial y alegó que ésta realizó: "Un pronunciamiento crítico sobre su legislación, señalando cual debiera ser, a su juicio, el procedimiento idóneo ante casos similares al denunciado". ${ }^{69}$ Debido a ello estimó lo inaceptable del fallo y su imposible ejecución, pues la Corte Interamericana se había excedido en sus funciones (atribuciones).

En el análisis de la acción de control, la Sala Constitucional determinó la naturaleza de la Convención Americana como: "Un tratado multilateral que tiene jerarquía constitucional y prevalece en el orden interno solo en la medida en que contengan normas sobre su goce y ejercicio más favorables a las establecidas en la Constitución", ${ }^{70}$ pues el artículo 23 de su constitución dispone que: "Los tratados, pactos y convenciones relativos a derechos humanos, suscritos y ratificados por Venezuela, tienen jerarquía constitucional y prevalecen en el orden interno, en la medida en que contengan normas sobre su goce y ejercicio más favorables a las establecidas por esta Constitución y en las leyes de la República”. Y, desde su perspectiva, la protección que deriva de la Convención Americana es "coadyuvante o complementaria de la que ofrece el derecho interno de los Estados americanos". ${ }^{71}$ Y si bien coadyuva o complementa el texto fundamental, no otorga a los tratados sobre derechos humanos rango "supraconstitucional", por lo que en caso de antinomia o contradicción entre una disposición de la carta fundamental y una norma de un pacto internacional corresponde al Poder Judicial venezolano determinar cuál es aplicable. Finalmente, se adujo que no se pretendía interpretar el contenido y alcance de la sentencia de la Corte Interamericana, desconocer el tratado o eludir el compromiso de ejecutar sus decisiones, sólo aplicar un estándar mínimo de adecuación del fallo referido con el orden constitucional interno, pues de no hacerlo así "la ejecución de la sentencia de la Corte Interamericana afectaría principios y valores esenciales del orden constitucional de la República [...] y pudiera conllevar a un caos institucional en el marco del sistema de justicia". ${ }^{72}$ En efecto, el fallo del 5 de agosto de 2008 se declaró inejecutable y se solicitó al Ejecutivo que denunciara la Convención Americana por la evidente usurpación de funciones en que incurrió la Corte Interamericana.

\footnotetext{
69 Idem.

70 Idem.

71 Idem.

72 Idem.
} 
Así, el condenado se convirtió no sólo en demandante, sino incluso en juzgador, pues descalificó la idoneidad del proceso jurisdiccional seguido en su contra; la jerarquía y el ámbito de aplicación de la Convención Americana, así como la obligatoriedad del fallo de la Corte Interamericana. Puede advertirse que se cuestionaron las presuntas ilegalidades con otras mayores. El aparente desconocimiento de la naturaleza y jerarquía de las disposiciones contenidas en éste y en cualquier otro tratado en materia de derechos humanos, por parte del Estado venezolano, resulta simplemente inadmisible.

Toda vez que el Estado no informó sobre el cumplimiento de las medidas ordenadas por la Corte Interamericana, mediante resolución de su Presidencia, el tribunal resolvió convocarlo conjuntamente con la Comisión Interamericana y las víctimas o sus representantes a una audiencia privada en su sede el 29 de enero de 2010, con el propósito de obtener información sobre el cumplimiento de la sentencia y escuchar las observaciones de las otras partes. ${ }^{73}$ Se desconoce el sentido de la reunión. Si bien cabe precisar que, el 6 de agosto de 2009, en la Gaceta Oficial 39. 236 de la República Bolivariana de Venezuela se publicó el Código de Ética del Juez y la Jueza Venezolanos promulgado por la Asamblea Nacional; una de las obligaciones ordenadas en la sentencia de la Corte Interamericana del 5 de agosto de 2008; que, además, ocurre dentro del término de un año fijado para su cumplimiento por el Estado venezolano, ${ }^{74}$ si bien quedan obligaciones incumplidas para este miembro (todavía) del Sistema Interamericano de Derechos Humanos.

\section{EL PRECEDENTE COLOMBIANO}

La línea argumentativa utilizada por la Corte Suprema de Venezuela había sido planteada tiempo atrás a propósito de otro fallo de la Corte Interamericana que involucró a Colombia. Uno de los jueces de su Corte Suprema cuestionó diversas fallas dentro del proceso así como la sentencia dictada a en el caso

73 Corte IDH, Resolución de la Presidencia de la Corte Interamericana de Derechos Humanos del 18 de diciembre de 2009, Caso Apitz Barbera y Otros ("Corte Primera de lo Contencioso Administrativo") vs. Venezuela, Supervisión de cumplimiento de sentencia.

74 Asamblea Nacional, República Bolivariana de Venezuela, Decreto Ley http://www. oas.org/juridico/spanish/mesicic3_ven_anexo4.pdf. 
de los 19 Comerciantes vs Colombia. ${ }^{75}$ Dentro de ellas se destacaron las siguientes: a) la Corte dictó su propio Reglamento en noviembre de 2000. Sus reglas procesales no fueron aprobadas ni por la Asamblea de la OEA ni por ninguno de los estados miembros; b) según el artículo 44 de la Convención Americana, los particulares que se sientan lesionados por la violación de los derechos humanos deben presentar su queja o denuncia ante la Comisión Interamericana y ésta tomará la decisión de demandar o no; pero en el proceso contra Colombia, la Comisión fungió como demandante, como consecuencia, los comerciantes a que se aludió en la sentencia no fueron los actores (difícilmente lo serían si estaban muertos). El proceso tuvo como demandante a Colombia, representada por la Comisión Interamericana y simultáneamente a Colombia como demandada. Entonces, se cuestiona, ¿cómo se falla a favor de quien no fue parte en un proceso?; c) tratándose de la valoración de las pruebas se cuestiona: ¿cómo debe proceder la Corte?, su Reglamento no lo regula; d) la Corte dispuso que la prueba testimonial se convirtiera en prueba documental a fin de que los testigos no compareciesen y fueran contrainterrogados; e) el tribunal se convierte en juez revisor de las sentencias dictadas internamente para decidir la incompetencia del juez que absolvió a los militares implicados en las violaciones; f) el fallo también hace severas críticas a la perezosa actuación de la justicia colombiana, pero ello no puede ser motivo para desconocer sus decisiones y resolver de nuevo, pues se convertiría en tribunal de apelación desconociendo el principio de cosa juzgada; g) la Corte Interamericana se separó de lo demandado e hizo condenas no solicitadas, y h) la sentencia adolece de vicios que necesariamente conducen a decretar su nulidad.

Derivado de las supuestas fallas procesales, el juzgador cuestiona si vale la pena continuar vinculados a una organización internacional que maltrata, a través de su Corte, a los estados asociados:

¿es en verdad una Corte Interamericana de Derechos Humanos el cuerpo de jueces que viola el principio de la congruencia, la necesidad de que los testigos comparezcan ante el juez a declarar; el derecho de defensa de a quienes se les imputa, sin haberlos citado, la autoría intelectual de los asesinatos y

75 Segura Salceda, Jorge, "Una sentencia de la Corte Interamericana de Derechos Humanos y el caso de los 19 comerciantes vs. Colombia”, Revista Análisis Jurisprudencial, año 1, núm. 1, segundo semestre de 2006, Bogotá, D. C., http://www.encolombia.com/ derecho/RevistaJurisDiction/Asomagister11206/Asomagister11206Unasentencia.htm y http://www.corteidh.or.cr/pais.cfm?id_Pais=9. 
hurtos; el principio de la cosa juzgada; el respeto a la competencia de los jueces nacionales y que desconoce el derecho al debido proceso que, además de a los humanos, se le debe respetar también a los Estados?

En su argumento final sostuvo que, "no se podrá decir que, por ser una Corte internacional, contra sus decisiones no cabe recurso alguno. Tiene que haber alguna forma a través de la cual el Estado víctima haga valer sus derechos gravemente conculcados. Tal vez ¿una acción de tutela? ¿Un incidente de nulidad de sentencia?”. ${ }^{76}$ Puede apreciarse cómo Venezuela no hizo más que seguir los apuntamientos del juez colombiano para sustentar su defensa y justificar de algún modo la necesidad de desacatar la sentencia de la Corte Interamericana.

En el caso de los 19 Comerciantes vs Colombia se advierte cómo el juez se duele de la actuación de la Comisión Interamericana y, posteriormente, del fallo de la Corte Interamericana por vulneraciones al debido proceso; sin embargo, del análisis de las actuaciones se aprecia que fue el Estado quien utilizó los términos procesales en su favor — de forma dilatoria $\longleftarrow$ y sin ánimo de dar cumplimiento a la Recomendación formulada por la Comisión Interamericana en el Informe 76/00 del 4 de octubre de 2000, pues, pese a que solicitó una prórroga de un mes al plazo conferido originalmente para informar sobre las medidas que adoptaría en el plano interno, dio respuesta en el último día y en ella informó que sujetaba el cumplimiento de la Recomendación a las decisiones que, al respecto, tomara el Defensor del Pueblo; órgano al cual le encomendó fijar los plazos y las modalidades a tal fin, lo que en esencia incumplía las obligaciones contenidas en la Convención Americana. ${ }^{77}$

Los términos de la recomendación así como los responsables de su ejecución fueron claros: a) llevar a cabo una investigación completa, imparcial y efectiva en la jurisdicción ordinaria con el fin de juzgar y sancionar a los responsables de las diecinueve ejecuciones extrajudiciales; b) adoptar medidas para que los familiares de las víctimas recibieren adecuada y oportuna reparación por las violaciones, y c) adoptar las medidas necesarias para dar cumplimiento a la doctrina desarrollada tanto por la Corte Constitucional colombiana como por la Comisión en materia de investigación y juzgamiento

76 Idem.

77 Corte IDH, caso de los 19 Comerciantes vs. Colombia (Excepción Preliminar), párrafo 25, http://www.tc.gob.pe/corte_interamericana/seriec_93_esp.pdf. 
de casos similares, por la justicia penal ordinaria. Sin embargo, Colombia sólo trasladó la decisión de la Comisión Interamericana al ámbito interno, hacia el ombudsman, cuyas atribuciones constitucionales no guardan relación con las acciones requeridas para el cumplimiento de la Recomendación citada, pues no ejerce ni función jurisdiccional (decir el derecho en el caso concreto de manera imperativa) ni tampoco ejecutiva, esferas dentro de las cuales deberían tomarse las medidas necesarias para cumplir con los fines de la Recomendación. Luego, se pretendió hacer como que se cumplía, pero en los hechos se desacataba por falta de decisiones de fondo, lo que justificó que la Comisión Interamericana refiriera el caso a la jurisdicción de la Corte Interamericana, que a la postre emitió sentencia condenatoria contra Colombia. Por ello estimo que en este apartado procesal, quien no actuó de buena fe fue el Estado, al contrario de como lo aseveró el juzgador.

Respecto de la cuestión en torno a las reglas procesales que rigen la actuación de la Corte Interamericana, las mismas eran del conocimiento del Estado, por lo cual resultaba irrelevante debatirlas. Dentro del partido no se discuten las decisiones del árbitro: ¡se acatan! Si bien mi postura es que algunos criterios justifican un análisis detallado.

\section{CUESTIONAMIENTOS A LA JURISDICCIÓN DE LA CORTE INTERAMERICANA}

Pese a no compartir los argumentos expresados por los jueces constitucionales de Venezuela y Colombia para justificar un probable desacato a las sentencias de la Corte Interamericana, sí advierto algunas áreas de oportunidad en su actuación jurisdiccional susceptibles de mejora; por ejemplo, que dicta su propio Reglamento y fija las reglas procesales que rigen su jurisdicción acorde con lo dispuesto en el artículo 25 de su Estatuto. ${ }^{78}$ La aptitud de dictar sus normas procesales posibilita a cualquier ente ejercer discrecionalidad en el análisis de los puntos debatidos a su amparo y ocasionalmente puede afectar sus decisiones de certeza jurídica. Si bien otros tribunales como la Corte Internacional de Justicia y el Tribunal Europeo de Derechos Humanos hacen lo propio; aquélla en el artículo 30 de su Estatuto que prevé

78 Organización de los Estados Americanos, Estatuto de la Corte Interamericana de Derechos Humanos, Aprobado mediante Resolución 448 adoptada por la Asamblea General de la OEA en su noveno periodo de sesiones, celebrado en La Paz, Bolivia, octubre de 1979, http://www.oas.org/36ag/espanol/doc_referencia/Estatuto_CorteIDH.pdf. 
que formulará un reglamento mediante el cual determinará la manera de ejercer sus funciones (sus atribuciones y competencia) y establecerá sus reglas de procedimiento, ${ }^{79}$ y éste, acorde con lo dispuesto en el artículo 25 del Convenio para la Protección de los Derechos Humanos y de las Libertades Fundamentales que lo faculta para aprobar su Reglamento, ${ }^{80}$ la generalización, por sí sola, no lo convierte en el procedimiento idóneo. Los criterios jurisprudenciales del tribunal de aplicación preferente sobre la normativa van transformándola de tal modo que puede ocurrir lo que en México con el mecanismo de protección de los derechos humanos por excelencia: tener un juicio de amparo en la ley, uno diverso en los tribunales y otro más en la jurisprudencia, lo que a la larga dificultó su ejercicio al convertirlo en un proceso complejo.

Para reforzar este punto me parece de interés comentar algunos cuestionamientos formulados al máximo tribunal de México que tienen que ver con discrecionalidad en la aplicación de las reglas, los procesos y los procedimientos a que se sujetan sus atribuciones en términos de la Ley Reglamentaria de las Fracciones I y II del Artículo 105 de la Constitución Política de los Estados Unidos Mexicanos, pues, a partir de sus criterios jurisprudenciales, de forma constante ha expandido su ámbito de competencia para conocer de violaciones indirectas a la Constitución — de legalidad-, lo que no le fue atribuido por el Constituyente Permanente y ha sido cuestionado, incluso, por algunos de sus integrantes. La Suprema Corte de Justicia de la Nación, caso por caso, ha justificado su actuación apelando "al espíritu del Constituyente" o al "espíritu del dictamen del Senado". Y si esta orientación suele cuestionarse tratándose de un tribunal doméstico, que resuelve conflictos entre órganos del Estado y niveles de gobierno, debe ponderarse si resulta plausible tratándose de otro que delimita el alcance de las obligaciones de los estados soberanos mediante la interpretación y la aplicación de las cláusulas de la Convención Americana. La Corte o propio con apoyo en el "espíritu de la ley" o el "espíritu de la Convención". ${ }^{81}$ Salvo

${ }^{79}$ Corte IJ. Estatuto de la Corte Internacional de Justicia, http://www.un.org/spanish/ aboutun/icjstat.htm.

${ }^{80}$ Convenio para la Protección de los Derechos Humanos y de las Libertades Fundamentales, Roma, 4-XI-50, http://biblio.juridicas.unam.mx/libros/4/1740/28.pdf, http:// www.echr.coe.int/NR/rdonlyres/1101E77A-C8E1-493F-809D-800CBD20E595/0/ESP CONV.pdf.

81 Corte IDH, Barrios Altos vs. Perú, Sentencia del 14 de marzo de 2001, Serie C, núm. 75 y Blake vs. Guatemala, Sentencia del 2 de julio de 1996 (excepciones preliminares). 
que se asuma que la finalidad en la protección y la naturaleza del órgano: un tribunal de equidad que necesariamente debe buscar el equilibrio procesal entre partes que observan una relación tan disímil, lo justifique, pues, en algunos casos, se advierte liberalidad para valorar elementos de juicio así como en la recepción y la admisión de elementos de prueba: circunstanciales, indicios y presunciones considerados cuando permiten inferir conclusiones sólidas sobre los hechos, los que podrán valorarse acorde a las reglas de la sana crítica y la experiencia, en particular cuando el Estado no contesta la demanda de manera específica. ${ }^{82}$ Tal vez será la única posibilidad de resolver el fondo.

Más aún, la Corte ha sostenido que "la defensa del Estado no puede descansar sobre la imposibilidad del demandante de allegarse pruebas que, en muchos casos, no pueden obtenerse sin la cooperación del propio Estado" ${ }^{83}$ Por ello en sus procedimientos contenciosos ha aplicado criterios flexibles en la recepción y valoración de las pruebas. ${ }^{84} \mathrm{Si}$ bien cabe advertir que la actuación de este modo se sustenta en jurisprudencia que el propio tribunal ha establecido y en la jurisprudencia internacional, como afirma el doctor Sergio García Ramírez, más que en reglas procesales contenidas en su normativa.

Otro tema cuestionado versa sobre la falta de definitividad en el ejercicio de recursos internos, por parte de las presuntas víctimas y el momento oportuno de hacer valer esta excepción. En el Caso de Venezuela vs. los 19 Comerciantes, la Corte Interamericana sostuvo que la misma "no se hizo valer por el Estado, de forma oportuna ante la Comisión". ${ }^{85}$ Y, toda vez que éste renunció a invocarla de forma tácita, una vez producida es irrevocable, pues fue concebida en su favor a fin de "dispensarlo de responder ante un

82 Corte IDH, Caso de los Niños de la Calle (Villagrán Morales y Otros) vs. Guatemala, Sentencia del 29 de noviembre de 1999 (Fondo), Serie C, núm. 63, párrafos 68 y 69, Caso de la "Panel Blanca" (Paniagua Morales y Otro) vs. Guatemala, Sentencia del 8 de marzo de 1998 (Fondo), Serie C, núm. 37, párrafo 72.

83 Corte IDH, Caso Gangaram Panday vs. Surinam, Sentencia del 21 de enero de 1994 (Fondo, Reparaciones y Costas), Serie C, núm. 16, párrafo 49.

84 García Ramírez, Sergio, "Algunos criterios recientes de la Corte Interamericana de Derechos Humanos, (1998)", Revista Cuestiones Constitucionales, Revista Mexicana de Derecho Constitucional, núm. 1, julio-diciembre de 1999, Biblioteca Jurídica Virtual, http://www.juridicas.unam.mx/publica/rev/cconst/cont/1/art/art5.htm.

${ }^{85}$ Corte IDH, Caso Apitz Barbera y Otros (Corte Primera de lo Contencioso) vs. Venezuela, Sentencia del 5 de agosto de 2008 (Excpeciones preliminares, Fondo, Reparaciones y Costas), párrafo 22. 
órgano internacional por actos que se le imputen, antes de haber tenido la ocasión de remediarlos con sus propios medios". ${ }^{86}$

Los artículos 46 y 47 de la Convención Americana establecen como requisitos para admitir toda petición o comunicación ante la Comisión Interamericana que se hayan interpuesto y agotado los recursos de la jurisdicción interna $\mathrm{y}$, en caso negativo, cuando faltare alguno, la Comisión debe declararla inadmisible, salvo que se sustente un caso de excepción: cuando no existe legislación, no se haya permitido el acceso a los recursos de la jurisdicción interna, se haya impedido agotarlos o exista retraso en su decisión. ${ }^{87} \mathrm{Si}$ bien en este caso, aun existiendo algún recurso para su defensa hubiere carecido de sentido, para las víctimas, hacerlo valer, dadas las condiciones políticas imperantes y la parcialidad habida en el tratamiento de su caso que contó con la aquiescencia del Ejecutivo de aquel país.

La Corte Interamericana ha establecido algunos criterios sobre la interposición de esta excepción: ${ }^{88}$ el Estado demandado puede renunciar en forma expresa o tácita a la invocación de esa regla; la excepción de no agotamiento de recursos internos, para que sea oportuna, debe plantearse en la etapa de admisibilidad del procedimiento ante la Comisión, antes de cualquier consideración en cuanto al fondo. Si no es así, se presume que el Estado renuncia tácitamente a valerse de ella. La falta de agotamiento de recursos es una cuestión de pura admisibilidad y el Estado que la alega debe indicar los recursos internos que es preciso agotar y acreditar que esos recursos eran adecuados y efectivos; es decir, se revierte la carga de la prueba.

En el propio Sistema Interamericano se han fijado algunos criterios referidos al debido proceso legal (conjunto de requisitos que deben observar las instancias procesales para que las personas tengan aptitud de defender de forma adecuada sus derechos $)^{89}$ como estándares a fin de garantizar la debida certeza jurídica:

86 Idem.

87 Corte IDH, Caso de las Niñas Yean Bosico vs. República Dominicana, Sentencia del 8 de septiembre de 2005, párrafo 57 y Almonacid Arellano y otros vs. Chile, Sentencia del 26 de septiembre de 2006 (Excepciones Preliminares, Fondo, Reparaciones y Costas), párrafo 26.

88 Ibidem, párrafo 61.

${ }^{89}$ Cfr. El acceso a la justicia como garantía de los derechos económicos, sociales y culturales. Estudio de los estándares fijados por el Sistema Interamericano de Derechos Humanos, http://www.cidh.oas.org/countryrep/accesodesc07sp/accesodesciv.sp.htm. 
a) cualquier actuación de los órganos estatales dentro de una causa administrativa o jurisdiccional debe respetar el debido proceso legal;

b) quienes ejerzan funciones materialmente jurisdiccionales tienen el deber de adoptar decisiones justas basadas en el respeto pleno a las garantías del debido proceso;

c) en la extensión y alcances de las decisiones judiciales se debe reflejar un análisis de fondo que razone la conclusión y determine la procedencia o improcedencia de la pretensión jurídica que dio origen al recurso judicial, y

d) la Corte carece de competencia para convertirse en una "nueva y última instancia" para resolver los planteamientos originales de las partes en un proceso nacional. ${ }^{90}$

El debido proceso legal debe observarse desde la perspectiva de todas las partes. Si bien la Corte Interamericana ha determinado que en la jurisdicción internacional la observancia de "ciertas formalidades", no siempre es relevante, pues lo esencial es que se preserven las condiciones necesarias para que los derechos de las partes no sean disminuidos o desequilibrados y se logren los fines para los cuales han sido diseñados los distintos procedimientos. ${ }^{91}$

En los procedimientos deben observarse los principios de buena fe y de interpretación pro homine ${ }^{92}$ en la búsqueda de la optimización de la norma para alcanzar sus fines. Y estos principios "miran” más a la persona humana que al ente estatal. Por ello, la combinación de atribuciones a cargo de la Comisión, pues asume tanto caracteres de ombudsman como de fiscal: formula recomendaciones a los gobiernos de los Estados en favor de los derechos humanos; les solicita informes sobre las medidas adoptadas

90 Cfr. Corte IDH, Voto razonado de Ferrer Mac-Gregor Poisot, E. "Caso Cabrera García y Montiel Flores vs. México". Si bien la interpretación de la Corte ha considerado que "si el Estado ha violado o no sus obligaciones internacionales en virtud de las actuaciones de sus órganos judiciales, puede conducir a que este Tribunal Interamericano deba ocuparse de examinar los respectivos procesos internos para establecer su compatibilidad con la Convención Americana, lo cual incluye, eventualmente, las decisiones de tribunales superiores".

91 Corte IDH, Caso Loayza Tamayo vs. Perú, Sentencia del 27 de noviembre de 1998 (Reparaciones y Costas), párrafo 38.

92 Corte IDH, Jorge Castañeda Gutman vs. Estados Unidos Mexicanos, op. cit., nota 42 , párrafo 65 . 
en la materia; gestiona y posibilita que las partes lleguen a una solución amistosa del asunto y tiene derecho de someter los casos a la decisión de la Corte Interamericana, justo, porque no es un órgano judicial como refiere la jurisprudencia en la materia. ${ }^{93}$ Lo anterior lo corrobora el artículo 28 del Estatuto, que señala que la Comisión será tenida como parte ante la Corte Interamericana en todos los casos relativos a su función jurisdiccional. Luego, la Comisión es parte, no juez, pues la función jurisdiccional acorde a la Convención Americana sólo la desarrolla el tribunal y acorde con las "garantías judiciales" debe asegurar la debida imparcialidad en su actuación. Por lo argumentado, llama la atención que ante la Comisión Interamericana se puedan renunciar derechos de índole procesal, pues la jurisprudencia sostiene que la excepción de no agotamiento de recursos internos debe plantearse en la etapa de admisibilidad del procedimiento ante la Comisión, no en el proceso. De no haberse planteado la objeción en su oportunidad procesal: "El Estado está impedido — en virtud del principio estoppel (de los actos propios) — de hacerla prevalecer ante este Tribunal, porque ha renunciado tácitamente a ella". ${ }^{94}$

Si bien cabe mencionar que este criterio jurisprudencial es de reciente cuño, pues en la sentencia pronunciada en el conocimiento del Caso Velásquez Rodríguez vs. Honduras (Excepciones Preliminares), la Corte Interamericana sustentaba otro diverso: "Las cuestiones relativas al agotamiento y efectividad de los recursos internos aplicables al presente caso deben ser resueltas junto con las cuestiones de fondo". En él desestimó todas las excepciones preliminares opuestas por Honduras, salvo ésta.

\section{ENCRUCIJADA ACTUAL}

De lo analizado hasta ahora se advierten áreas de oportunidad para el perfeccionamiento del Sistema Interamericano de Derechos Humanos; al menos por lo que atañe a la competencia contenciosa de la Corte Interamericana. No es propio de un órgano fijar las reglas que sujetarán su actuación y carecer de límites precisos en su ejercicio, aun como tribunal de

93 Corte IDH, op. cit., nota 74.

94 Corte IDH, Caso Ximenez Lopez vs. República Federativa de Brasil, Sentencia del 30 de noviembre de 2005 (Excepción Preliminar), párrafo 5 y Caso Hermanas Serrano Cruz vs. El Salvador, sentencia del 23 de noviembre de 2004 (Excepciones Preliminares), párrafos 130 y 135. 
equidad; ello pudiera producir su deslegitimación. La propia Corte se ha auto limitado en el conocimiento de algunos casos; sin embargo, algunos de sus juece ponderan la necesidad de que intervenga aun cuando no se hayan producido afectaciones a los derechos humanos en un caso concreto, cuando por la sola emisión de una norma ésta contraríe las disposiciones de la Convención Americana: la realización de un examen in abstracto ; ¿por qué no hacerlo? Bastaría con que la Corte lo determinara. En otros casos, por ejemplo, la propia Corte ha reiterado que no existe "disposición alguna en la Convención ni en los Reglamentos de la Corte y de la Comisión que regule de manera expresa aspectos relativos al análisis o valoración que debe realizar la Comisión de la respuesta del Estado a las recomendaciones formuladas en el informe del artículo 50 de la Convención"; si se requieren ¿por qué no redactarlas? ${ }^{95}$

Si dado su carácter de tribunal de equidad, al cual le corresponde velar por una materia tan sensible como lo es la tutela de los derechos humanos, requiere de reglas diversas a las que rigen en el derecho interno de los respectivos países y mayor flexibilidad en sus procedimientos, las mismas deberían construirse e incluso irse modificando acorde a las necesidades de protección; pero que no sean sus propios integrantes los que determinen, caso por caso, el ajuste de la normativa. Sería mejor opción incorporar en ella la doctrina jurisprudencial que de forma paulatina perfecciona los términos de su competencia jurisdiccional. Si ella misma puede construir las reglas que sujetan su jurisdicción (dictar su Reglamento), con mayor razón puede modificarlo con este fin.

Por cuanto a las posturas que podremos adoptar ante sus fallos, las mismas seguramente se orientarán acorde al tipo de Estado al que aspiremos, pero, en todo caso, deben acatarse; en ello estriba su carácter definitivo e inapelable. A tal fin cuenta con facultades para supervisar el cumplimiento de sus decisiones imperativas y les da un seguimiento puntual hasta en tanto se adopten todas las medidas y se cumplan todas las reparaciones ordenadas. Cada Estado debe informar a detalle la forma y términos en que las cumplió. En caso de desacuerdo con el sentido o alcance del fallo, la Corte Interamericana lo interpretará a solicitud de cualquiera de las partes, siempre que se le presente dentro de los noventa días contados a partir de la fecha de su notificación.

95 Corte IDH, Caso Velásquez Rodríguez vs. Honduras, Sentencia del 26 de junio de 1987 (excepciones preliminares), párrafo 96. 
Venezuela amenazó con retirarse del Sistema Interamericano de Protección por estar en desacuerdo con la sentencia dictad en el caso de los 19 Comerciantes, pero sigue dentro del mismo y cumplió parte de la sentencia de la Corte. Perú aprobó el retiro del reconocimiento de la competencia contenciosa (cláusula facultativa) de la Corte Interamericana el 9 de julio de 1999 y mediante Resolución Legislativa No. 27152, de 8 de julio de 1999 efectuó el acta de depósito ante la Secretaría General de la OEA en la cual determinó sus efectos inmediatos, al estimar que en el fallo del caso Petruzzi y otro "se desconoce la Constitución y la ley interna del Perú al cuestionar la competencia de los tribunales militares para juzgar a civiles por los delitos de Terrorismo y de Traición a la Patria". Pese a ello, la Corte Interamericana determinó que el pretendido retiro con efectos inmediatos de la competencia contenciosa de la Corte resultaba inadmisible. El Estado sigue sujeto a su jurisdicción. Trinidad y Tobago que signó la Convención Americana y reconoció la jurisdicción obligatoria de la Corte Interamericana, notificó al Secretario General de la OEA la resolución en que denuncia la Convención Americana (26 de mayo de 1998) con motivo de un diferendo en torno a su artículo 62 y sobre su Reserva por la cual reconoce la jurisdicción obligatoria de la Corte Interamericana, pero: "Sólo en la medida en que tal reconocimiento sea compatible con las secciones pertinentes de la Constitución de la República de Trinidad y Tobago, y siempre que una sentencia de la Corte no contravenga, establezca o anule derechos o deberes existentes de ciudadanos particulares". Mediante sentencia, la Corte Interamericana resolvió que dicha limitación es incompatible con el objeto y fin de la Convención. La denuncia entró en vigor un año después de la fecha de notificación conforme al artículo 78(1) de la Convención Americana.

Respecto de las condenas pronunciadas contra el Estado mexicano, ¿quién podría oponerse a la construcción de escuelas y de un centro comunitario en el que se desarrollen actividades educativas en materia de derechos humanos en la Sierra de Guerrero? ¿A la adopción de medidas para que las niñas de la comunidad de Barranca Tecoani cuenten con facilidades de alojamiento y alimentación que les permitan continuar sus estudios o a que les instalen aulas en su comunidad a tal fin? ¿Al otorgamiento de becas de estudios en beneficio de quien lo necesite? ¿A continuar campañas de concientización y sensibilización de la población sobre los efectos de la violencia y la discriminación de género? ¿A la implementación de programas permanentes de capacitación sobre investigación diligente en casos de tratos crueles, 
inhumanos o degradantes y tortura? Pero, lo que resulta vergonzoso es que sea un órgano jurisdiccional allende nuestras fronteras, el que lo ordene ante el incumplimiento de las autoridades para brindar mínimos de tutela a sus gobernados y la falta de garantías efectivas para la defensa y vigencia de sus derechos fundamentales.

Admitir los razonamientos y conclusiones que interpretan de forma expansiva la tutela de los derechos humanos, pese a que algunos estados argumenten visos de incertidumbre en su competencia, extralimitación en sus atribuciones, vaguedad en su desempeño procesal y deficiencias argumentativas, lo que en los casos analizados resultó impreciso, al respaldar que la tutela efectiva de los derechos humanos es el motivo, justificación y fin de la institución jurisdiccional u optamos por otra corriente de pensamiento que sostiene que como tribunal debe regirse por reglas procesales que brinden certeza a sus decisiones y garanticen la seguridad jurídica para los estados sometidos a su jurisdicción: se garantiza la debida seguridad jurídica de los estados sujetos a su jurisdicción o se tutelan de mejor manera los derechos humanos; estimo que debemos encontrar un punto intermedio que concilie ambas visiones. De no ser factible, resulta preferible optar por este último enfoque, pues debemos tener presente - en todo momentoque se trata de un tribunal de equidad y que lo sometido a su jurisdicción en busca de remedio son violaciones a los derechos esenciales de toda persona humana que, todavía hoy, en muchos países de la región siguen sin protección efectiva. Infortunadamente, México no es la excepción. Elevar a rango constitucional los tratados en la materia posibilitará terminar con los cuestionamientos sobre su jerarquía; pero me parece que la desprotección de los derechos humanos en México, no se vincula con deficientes medidas legislativas, sino con políticas públicas desatinadas y la incuria de las autoridades (particularmente las administrativas) que estiman que son "un estorbo" en el cumplimiento de sus atribuciones. Tal vez a estas tareas son a las que debamos dedicar nuestros mayores esfuerzos. En tanto, debe darse cabal cumplimiento a las condenas pronunciadas en su contra, pues ni la primera de ellas lo está de forma integral, pese al tiempo transcurrido. 